\title{
CHARACTER EDUCATION AT SEKOLAH ALAM MINANGKABAU AND SEKOLAH ALAM AR-ROYYAN PADANG
}

\author{
* Indah Pertiwi ${ }^{1}$ and Syafri Anwar ${ }^{2}$ \\ ${ }^{\mathbf{1}}$ Master Program of Social Science of Universitas Negeri Padang \\ ${ }^{2}$ Lecturer Master Program of Social Science of Universitas Negeri Padang \\ Email: indahpertiwi@student.unp.ac.id \\ *Corresponding Author, Received: March 10, 2020, Revised: May 17, 2020, Accepted: June 10, 2020
}

\begin{abstract}
This research discloses how character education builds students' character at Sekolah Alam Minangkabau and Sekolah Alam Ar-Royyan Padang, so students not only have knowledge capabilities but also provide character social attitudes. This is a qualitative typified research. The data were collected through observation, interviews, and document analysis. The validity of the data was examined through the triangulation method while Miles and Huberman's theory of analysis were used in analyzing the data. The results of the research suggest that: The characters of the students in both schools are religious, tolerant, obedient, diligent, creative, independent, curious, communicative, ecofriendly, and responsive. The students' character is built through macro and micro strategies. The varieties of the character education used in both schools include the curriculum, facility, educational program, extracurricular as well as the time and the way the character education is implemented. The students' parents view the character education as a support for them in developing their children's personality, it influences the students' daily activities outside the schools, and moreover, it also establishes a good communication between the teacher and the students' parents.
\end{abstract}

\section{Keywords: Education, Character, Sekolah Alam}

\section{INTRODUCTION}

Responding to the development of an increasingly advanced era, it requires a better education as well. That is why education is now one thing that needs to be considered. Not only academic education, but also the character of education. However, the world of education more often only pays attention to academic education in the level of knowledge alone without involving social attitudes on students. Practice questions, quizzes, and exams are often the only way to measure student learning outcomes at school. Meanwhile, an education program cannot only discuss one side, there needs to be a balance between the measuring instruments used by each school, such as by including an assessment of the social attitude of students, so that schools do not only have good support on the academic side without being equipped character 
http://ijeds.ppj.unp.ac.id/index.php/IJEDS

education. Which can increase to the urgency of character education by diverting great people into knowledge but cannot be ethically correct in supporting the process. This kind of thing is common in schools that are no exception schools in the city of Padang.

One form of effort that can be done to balance students' knowledge and social attitudes is to carry out character education in schools. As stated by Ki Hajar Dewantara (1889-1959) which mentions education is an effort to advance the growth of character (inner strength, and character), mind (intellect) and the child's body, in the framework of the perfection of life and harmony with his world (Saidah, 2016). In the implementation of character education schools can develop strategies and include the role of parents so that character education for students can run optimally. That way the urgency of character education in students can be overcome through the presence of character education in schools.

So to respond to the problems outlined above, questions arose regarding character education at Sekolah Alam Minangkabau and Sekolah Alam Ar-Royyan Padang. With the formulation of the research problem what are the characters at Sekolah Alam Minangkabau and Sekolah Alam Ar-Royyan Padang, how is the character formation strategy at Sekolah Alam Minangkabau and Sekolah Alam Ar-Royyan Padang, what are the variations in the implementation of character education at Sekolah Alam Minangkabau and Sekolah Alam ArRoyyan Padang, and how parents' views of character education at Sekolah Alam Minangkabau and Sekolah Alam Ar-Royyan Padang. For the answer, in-depth research will be conducted and the results will be made into a journal entitled "character education at Sekolah Alam Minangkabau and Sekolah Alam Ar-Royyan Padang".

\section{METHOD}

This type of research used in this study is the type of qualitative research with descriptive research type. This research was conducted at Sekolah Alam Minangkabau and Sekolah Alam Ar-Royyan Padang. The selection of research informants was carried out by purposive sampling of 30 research informants. Data collection techniques used were observation, interviews, and document studies. The data validity checking technique used is triangulation which includes source triangulation, technique triangulation, investigator triangulation, and time triangulation. The data analysis technique used is the Milles and 
http://ijeds.ppj.unp.ac.id/index.php/IJEDS

Huberman analysis model which consists of data collection, data reduction, data presentation, drawing conclusions.

\section{RESULTS AND DISCUSSION}

\section{Character of Students at Sekolah Alam Minangkabau and Sekolah Alam Ar- Royyan Padang}

In the Sekolah Alam Minangkabau and Sekolah Alam Ar-Royyan Padang each student is equipped with some character education formed by the school so that students have characters in the form of religious character, tolerance character, discipline character, hard work character, creative character, independent character, curiosity character, communicative character, environmental care character, and responsibility character.

This is in accordance with what was conveyed by Prochaska \& D'Clemente 1982 (in Zubaedi, 2011) that in behavior change there are five stages until the behavior actually occurs. First, the initial condition of someone who is basically human does not want to change behavior, second, the stage to consider changing, third, the stage of making a little change. Fourth, the stage where a person starts to be bound by new behavior. Fifth, the stage of maintaining new behavior. Thus character education is all the efforts made by teachers, which are able to influence the character of students. This includes exemplary how the teacher's behavior, the way teachers talk or deliver material, how teachers tolerate, and how other related matters (Zubaedi, 2011).

A person who is well-educated in character will produce commitment, loyalty, awareness and willingness to hold and fulfill applicable ethics. This is in line with the explanation that the essence of ethical meanings or moral knowledge is good behavior that is done intentionally, so moral knowledge is what one should do voluntarily (Zubaedi, 2011).

\section{The Strategy of the Character Building at Sekolah Alam Minangkabau and Sekolah Alam Ar-Royyan Padang}

a. Religious. In the Sekolah Alam Minangkabau, religious character education is formed in a macro form with the Duha prayer activities in congregation, midday prayer activities, congregational prayer activities and studying through the planning stage by holding a school meeting between the homeroom teacher and the principal 
http://ijeds.ppj.unp.ac.id/index.php/IJEDS

to arrange a schedule of activities / subjects for one semester, then the homeroom teacher conducts socialization to students' parents through parent / guardian student meetings, then informs students about the schedule of activities / subjects, then the homeroom teacher explains each point of the schedule of activities / subjects that students will carry out. At the implementation stage all activities are carried out under the direction and supervision of the picket teacher and homeroom teacher. Beginning with students taking wudlu together. For Duha prayers students carry out in their classrooms in congregation, while for Zuhr prayers and Asr Prayers students perform in one saung (class) together with students who come from other classes in congregation followed by chanting together. At the evaluation stage the picket teacher and homeroom teacher checks the student attendance when all activities are carried out. In the Sekolah Alam Ar-Royyan, religious character education is formed in a macro form with the activities of the Duha Prayers in congregation, the midday prayer activities, the Asar Prayers in congregation, Wafa or the Koran study and conveys about other religious values which also need to be formed by students such as praying before learning. At the planning stage the teacher and the principal hold a joint meeting to arrange a schedule of activities / subjects in the school hall, then the homeroom teacher tells the parents / guardians of the student the activity / subject schedule by holding a class meeting, followed by notifying students. At the implementation stage for the prayer activities in congregation begins with taking ablution. For those who pray in congregation are held at the school mosque, those who pray in congregation are held in classrooms. For praying before eating activities seen students carry out prayer activities together in class. At the evaluation stage each series of activities is carried out under the supervision of the teacher, wafa or recitation activities are also carried out under the supervision of the teacher, while the activity of praying together before lunch, the homeroom teacher also prayed while paying attention to whether all students prayed or not.

b. Tolerance. In the Sekolah Alam Minangkabau the character of tolerance education is formed in a micro form in the form of creating a school culture by not discriminating between religious differences between students, aware of themselves as majority or minority, non-Muslim students wait in class when Muslim students worship, non-Muslim students participate reminding friends his friends to perform 
http://ijeds.ppj.unp.ac.id/index.php/IJEDS

ablution and pray, non-Muslim students reprimanded if there are Muslim students who play around during prayer. At the Sekolah Alam Ar-Royyan character education is shaped micro-tolerance in the form of creating a school culture with mutual respect for differences in ethnicity, customs and opinions.

c. Discipline. At the Sekolah Alam Minangkabau character education in students is formed in a macro and micro discipline. Macro character formation is carried out by implementing school rules and regulations through the planning stage by compiling or updating school rules and regulations during school meetings, then the teacher socializes to students the school rules and regulations, at the implementation stage students carry out each point of the rules and school rules, at the evaluation stage the teacher and school apparatus check or supervise when students implement school rules and regulations. Micro character building is formed by creating a school culture that makes students accustomed to carrying out all the school rules and regulations. At the Sekolah Alam Ar-Royyan the discipline of character education for students is shaped both macro and micro. Macro character formation is carried out by carrying out school rules through the planning stage by compiling school rules or updating existing rules, socializing the code of conduct to students, At the implementation stage students carry out every point in the code, at the teacher evaluation stage the class is tasked with seeing and observing whether students undergo their obligations such as existing tetib order or not. Micro character building is formed by creating a school culture that allows students and school residents to be accustomed to building disciplinary activities while still being guided by school discipline.

d. Hard work. In the Sekolah Alam Minangkabau the character of hard work education for students is shaped micro through learning activities in the classroom, the creation of school culture and cocuricular activities. In the classroom teaching and learning activities carried out through the application of teaching and learning strategies by building enthusiasm for students when working on exercises, the creation of a school culture of character education hard work students are formed by making every activity that is of positive value as a habit on students. In the cocurricular activities the character of hard work in students is formed through the students' training activities in participating in the co-curricular activities. At the 
http://ijeds.ppj.unp.ac.id/index.php/IJEDS

Sekolah Alam Ar-Royyan the character of hard work training for students is formed micro, through teaching and learning activities in the classroom, the creation of school culture, and co-curricular activities. In teaching and learning activities in the hard work character education class students are formed by getting used to work when working on practice questions, in the creation of school culture hard work character education in students is formed by making students' abilities when trying to solve practice questions a habit. In the co-curricular activities character education of hard work on students is formed through co-curricular training activities.

e. Creative. At the Sekolah Alam Minangkabau the education of creative characters in students is formed in a macro that will ultimately create a work. As implemented in class 1 , in the planning stage the homeroom teacher class 1 determines the work to be made by students in the form of a used cardboard pencil case decorated using colored beach sand, then the homeroom teacher tells the administration section to prepare the equipment. At the implementation stage the teacher gives direction to the students what are the series of activities during making pencil cases. At the evaluation stage the homeroom teacher collects the work of the students and makes an assessment and is presented by the student in front of the receipt of the second term report card in the form of a report card / fortfolio. At the Sekolah Alam ArRoyyan the character of hard work training for students is formed microcularly through co-curricular activities where the school has provided some co-curricular activities for students to follow in accordance with their talents and interests which are carried out every Friday at 13.30.

f. Mandiri. At the Sekolah Alam Minangkabau, independent character education for students is formed in a microcomputer by creating a school culture through trading or trading activities to increase student independence in the field of entrepreneurship. At the Sekolah Alam Ar-Royyan, independent character education for students is formed microcularly through co-curricular activities through the supercamp program, which is camping.

g. Curiosity. At the Sekolah Alam Minangkabau the character education of curiosity in students is shaped micro through teaching and learning in class. Like when working on a work activity in term 2. At the Sekolah Alam Ar-Royyan, character education is curious for students to be formed on a micro scale through co-curricular 
http://ijeds.ppj.unp.ac.id/index.php/IJEDS

activities. Like when making brooches from flannel fabric on the handscraft cocuricular.

h. Communicative. In the Sekolah Alam Minangkabau, communicative character education for students is formed in a micro way by creating a school culture, by not discriminating between friends who have special needs and normal students. At Sekolah Alam Ar-Royyan communicative character education for students is also formed in a microcomputer by creating a school culture in which students are taught about polite and polite attitudes and friendly attitudes by not discriminating against friends.

i. Environmental care. In the Sekolah Alam Minangkabau character education care for students is formed micro by creating a school culture by making teachers an example for students so students are motivated to care for the environment (Hermon, 2015). At the Sekolah Alam Ar-Royyan, character education cares about the environment for students formed in a microcomputer by creating a school culture by singing a song through the school's microphone with a glance at the direction so that students throw trash in the trash.

j. Responsible. In the Sekolah Alam Minangkabau character education responsibilities for students are formed in a micro way that makes responsibilities as school culture as by carrying out obligations for class picket. At the Sekolah Alam Ar-Royyan character education responsibility for students is formed in a micro manner by creating a school culture also through class picket activities.

The strategy of character formation in macro and micro as described above is in line with what was written in (Mahmud 2017) in macro character development divided into three stages, namely planning, implementation, and evaluation of results. At the planning stage, a set of characters is developed which is dug up, crystallized, and formulated using sources, including philosophical considerations: Pancasila, the 1945 Constitution, and Law No. 20 of 2003 along with the provisions of the legislation derived from them, theoretical: theories about the brain, psychological, education, values and morals, as well as socio-cultural, empirical: in the form of the best experiences and practices, including figures, superior education units, pesantren, groups culture. In the implementation phase, learning experiences and learning processes are developed that lead to the development of character in learners. At the evaluation stage of the results, an assessment program for continuous improvement is designed and 
http://ijeds.ppj.unp.ac.id/index.php/IJEDS

implemented to detect the actualization of character in learners as an indicator that the process of civilizing and acculturating the character is successful, producing strong attitudes, and argumentative thoughts. Character education in the micro context, centered on the education unit holistically. Character development is divided into four pillars, namely teaching and learning activities in class, daily activities in the form of educational unit culture development, co-curricular and / or extra-curricular activities, as well as daily activities at home and community.

\section{The Variation Implementation of Character Education at Sekolah Alam Minangkabau and Sekolah Alam Ar-Royyan}

Variations in the implementation of character education in the Sekolah Alam Minangkabau and Sekolah Alam Ar-Royyan are located in the curriculum, in the Sekolah Alam Minangkabau the school uses the National Curriculum and the specific curriculum of the Sekolah Alam Minangkabau and in the Sekolah Alam Ar-Royyanusing the National Curriculum, Integrated Islamic school network curriculum, curriculum School of Nature, and inclusive curriculum; extracurricular activities, at the Sekolah Alam Minangkabau, the extracurricular activities available are randai and at the Sekolah Alam Ar-Royyan, extracurricular activities available are the Qur'an recitation, scouting, sports (futsal, karate, swimming, badminton), arts and languages (written works, art painting, percussion, language clubs), science, cooking, and handicraft; facilities, at the Sekolah Alam Ar-Royyan facilities provided in the form of school buildings, playing fields, learning media, toilets, kitchens, and halls and at the Sekolah Alam Ar-Royyan facilities provided in the form of school buildings, parks and playing fields, swimming pools and outbound facilities, learning media, school buses, mosques, toilets, and canteens; execution time; and forms of implementation. Although there are some variations in the implementation of character education in the Sekolah Alam Minangkabau and the Sekolah Alam Ar-Royyan, the purpose of character education remains well conveyed to students.

This is in accordance with the first goal of character education is to facilitate the reinforcement and development of certain values so that it manifests in the behavior of children, both during the school process and after the school process (after graduating from school). Strengthening and developing have the meaning that education in school settings is not just a dogmatization of values to students, but a process that brings students, to understand and reflect 
http://ijeds.ppj.unp.ac.id/index.php/IJEDS

on how a value becomes important to be realized in human daily behavior, including for children. Strengthening also directs the education process to the habituation process which is accompanied by logic and reflection on the process and the impact of the habituation process carried out by the school both in classroom and school settings. Strengthening also means that there is a relationship between strengthening behavior through habituation at school and habituation at home (Dharma Kusuma et al, 2012).

\section{The Students' Parents View the Character Education at Sekolah Alam Minangkabau and Sekolah Alam Ar-Royyan Padang}

First, the existence of character education in schools helps parents in shaping student personality by making character education as a habit to students and students can transmit their habits to family members at home. Secondly, the existence of character education in schools held in the daily lives of students outside of school, namely compilation within the student's family, becomes aware of his duties and responsibilities as a child and compilation in the community of students to know how to connect to socialize the people around him. Third, through character education in schools there is good communication between the homeroom teacher and students' parents, namely through direct discussions at school when receiving report cards between parents of students and homeroom teachers and through whatsapp class groups.

So, there is no need to doubt, that is the intended character education which must involve all parties of the household and school family, the wider environment. Therefore, it is necessary to reconnect the education networks and connections that are starting to break up. This character of education will not succeed as long as there is no continuity between harmony and harmony between educational environments. Thus, the household and family as an environment of formation and education of the first and foremost characters must be more empowered (Manur Muslich, 2011).

\section{CONCLUSION}

The existence of character education at the Sekolah Alam Minangkabau and Sekolah Alam Ar-Royyan Padang is an effort made by the school to avoid urging the urgency of character education for students in the midst of the times. Through character education, schools try to shape the character of students from an early age. The implementation of character 
http://ijeds.ppj.unp.ac.id/index.php/IJEDS

education cannot be separated from the collaboration of schools, teachers, and parents of students so that the education received by students is more directed and controlled both when students are at school and when students are out of school. So that character education can be a foundation for schools, teachers and parents to shape behavior in students.

\section{REFERENCES}

Afifuddin. 2012. Metodologi Penelitian Kualitatif. Bandung: Pustaka Setia Bungin, Burhan. 2011. Metodologi Penelitian Kualitatif. Jakarta: Rajawali Pers

Faisal, Sanapiah. 1990. Penelitian Kualitatif Dasar-dasar dan Aplikasi. Malang: YA3 Malang Idrus, Muhammad. 2009. Metode Penelitian Ilmu Sosial Pendekatan Kualitatif dan Kuantitatif. Jakarta: Erlangga

Iskandar. 2009. Metode Penelitian Pendidikan dan Sosial. Jakarta: Gaung Persada Press

Kusuma, Dharma, dkk. 2012. Pendidikan Karakter Kajian Teori dan Praktik di Sekolah. Bandung: Remaja Rosdakarya

Gunawan, Heri. 2017. Pendidikan Karakter Konsep dan Implementasi. Bandung: Alfabeta Hermon, D. 2015. Arahan Kebijakan Keberlanjutan Pendidikan 10 Tahun Pasca Bencana Tsunami di Kabupaten Aceh Jaya Provinsi Aceh. Seminar Nasional Geografi. Master Program of Geography Education. Universitas Negeri Padang

Moleong, L, J. 2009. Metodologi Penelitian Kualitatif. Bandung: Remaja Rosdakarya

Musclich, Masnur. 2011. Pendidikan Karakter Menjawab Tantangan Krisis Multidimensional. Jakarta: Bumi Aksara

Ritzer, George. 2014. Teori Sosiologi Modern. Jakarta: Kencana Prenada Media Group

Saidah. 2016. Pengantar Pendidikan Telaah Pendidikan Secara Global dan Nasional. Jakarta: Rajawali Pers

Sugiyono. 2012. Metode Penelitian Pendidikan. Bandung: Alfabeta

Triwiyanto, Teguh. 2014. Pengantar Pendidikan. Jakarta: Bumi Aksara

Santoso, Satmoko Budi. 2010. Sekolah Alternatif, Mengapa Tidak...?! Buku Pintar Sekolah Alam/Outbound, Home Schooling, dan Anak Berkebutuhan Khusus. Jogyakarta: DIVA Press

Suyadi. 2013. Strategi Pemebelajaran Pendidikan Karakter. Bandung: Remaja Rosdakarya.

Wibowo, Agus. 2012. Pendidikan Karakter Strateg Membangun Karakter Bangsa Berperadaban. Yogyakarta: Pustaka Belajar

Yaumi Muhammad. 2014. Pendidikan karakter landasan, pilar \& implementasi. Jakarta: Kencana

Zubaedi. 2011. Desain Pendidikan Karakter Konsepsi dan Aplikasinya dalam Lembaga Pendidikan. Jakarta: Prenada Media Group 